\title{
DIAGNOSIS OF THE CARDIAC AUTONOMIC NEUROPATHY IN DIABETIC PATIENT ${ }^{\star}$
}

\author{
V. A. Shuper', S. V. Shuper ${ }^{2}$, Ju. O. Rykova ${ }^{3}$, \\ I. V. Trefanenko ${ }^{1}$, G. I. Shumko ${ }^{1}$, T. V. Reva ${ }^{1}$ \\ 1 Bucovinian State Medical University, Chernivtsi, Ukraine; \\ ${ }_{2}$ Yuriy Fedkovych Chernivtsi National University, Chernivtsi, Ukraine; \\ ${ }^{3}$ Kharkiv National Medical University, Kharkiv, Ukraine \\ sssrlug@gmail.com
}

World Health Organization estimates that the number of people with Diabetes Mellitus (DM) grew by nearly $300 \%$ from 1980 to 2014 , to 422 million worldwide. That number is also predicted to rise, to 642 million people living with diabetes worldwide by 2040 [1,2]. A close link exists between DM and cardiovascular disease (CVD). CVD is the most prevalent cause of mortality and morbidity in diabetic populations [3]. That relative risk in adults with DM ranges from 1 to 3 in men and from 2 to 5 in women compared to those without DM [4].

Cardiac autonomic neuropathy (CAN) is a very common diabetes-related complication that coexists with increased risk of renal disease, stroke, CVD and sudden death [5]. Based on the CAN Subcommittee of the Toronto Consensus Panel on Diabetic Neuropathy [6, 7], CAN is defined as the impairment of cardiovascular autonomic control in patients with established DM following the exclusion of other causes. The prevalence of CAN varies between $1 \%$ and $90 \%$ in patients with type 1 DM (DM 1) and $20 \%-73 \%$ in patients with type $2 \mathrm{DM}$ (DM 2) [8]. CAN may be detected by analysis of Heart Rate Variability (HRV) or standard cardiac autonomic reflex testing (CART), which are considered as the gold standard in clinical testing for autonomic neuropathy [9, 10]. Criteria for CAN diagnosis and staging are: one abnormal cardiovagal test result identifies possible or early CAN; at least two abnormal cardiovagal test results are required for definite or confirmed CAN; and the presence of orthostatic hypotension in addition to abnormal heart rate test results identifies severe or ad-

* The research was carried out as part of investigation work at the Department of Internal Medicine, Clinical pharmacology and Occupational diseases at Bucovinian State Medical University, Ministry of Health of Ukraine «Features of the comorbid flow of diseases of the internal organs: risk factors, mechanisms of development and mutual burdening, pharmacotherapy».(State registration number: 0114U002475). Institution, which financed the research: Bucovinian State Medical University, Ministry of Health of Ukraine.

The authors assume responsibility for the published work.

The authors guarantee absence of competing interests and their own financial interest when carrying out the research and writing the article.

The manuscript was received by the editorial staff 23.01.2019. 
vanced CAN. Progressive stages of CAN are associated with increasingly worse prognosis [7].

Despite the significant consequences CAN often remains undiagnosed for a prolonged period. Careful and timely testing of CAN with easy standard bedside tests in patients with DM 1 and 2 is critically important for early diagnoses and prophylaxes of further CV complications [11].

Aim of the study: to evaluate the CAN characteristics in DM 1 versus DM 2 patients and to identify the relationship between CAN and typical diabetic complications.

\section{MATERIALS AND METHODS}

A descriptive and comparative cross-sectional study was developed with 75 patients with DM (DM 1 - 30 patients, DM $2-45$ patients) during in-patient period of treatment (table 1). All patients were investigated routinely - complains, anamnestic data, objective examination, lab and instrumental tests.

Every participant was also examined for the peripheral neuropathy by testing for abnormal pin-prick sensations of the limbs, abnormality of position sense in the big toes, and the absence of Achilles' tendon reflex. Hypertensive patients and those with nephropathy were excluded from the study because of their likelihood of having baseline ECG abnormalities and possible interfering with the autonomic function tests. For defining of CAN five classical tests were done (CART): Evaluating of the resting tachycardia; Heart rate response to deep breathing; Valsalva maneuver; Systolic blood pressure response to standing; Diastolic blood pressure response to sustained handgrip $[10,12]$.

Statistical analyzes was carried out using licensed software products of Microsoft Office Professional 2003, the license of Russian Academic OPEN No Level No. 17016297. Descriptive statistics were calculated (the mean and standard deviation (SD) and $95 \%$ confidence interval (CI) for quantitative variables and percentages for qualitative variables).

\section{RESULTS AND THEIR DISCUSSION}

Most of the DM 1 patients (46.8\%) came to hospital for regular checkup, while only $6.5 \%$ of DM 2 were hospitalized for the same rea- son. 40 \% DM 1 and 80.5\% DM 2 needed to be hospitalized due to complaints of uncontrolled glycaemia, hyposensation and pain of extremi-

Characteristic of patients

\begin{tabular}{c|c|c}
\hline Points & DM type 1 & DM type 2 \\
\hline No of patients & 30 & 45 \\
\hline Mean age, years & $30.21 \pm 10.96$ & $50.17 \pm 8.84$ \\
\hline Mean age of onset of DM, years & $19.43 \pm 7.7$ & $43.18 \pm 9.21$ \\
\hline Male: Female ratio & $17: 13(1,3: 1)$ & $17: 28(1: 1.5)$ \\
\hline Duration of the DM, years & $11.34 \pm 7.76$ & $8.33 \pm 3.7$ \\
\hline Mean BMI, kg/m ${ }^{2}$ & $23.0 \pm 3.12$ & $29.24 \pm 6.18$ \\
\hline Positive family history & $7(23.3 \%)$ & $18(40 \%)$ \\
\hline History of the pancreatitis & $8(27.3 \%)$ & $15(30 \%)$ \\
\hline
\end{tabular}

Table 2

Results of routine diabetic tests

\begin{tabular}{|c|c|c|}
\hline Tests & DM 1 & DM 2 \\
\hline Mean HbA1c level, \% & $13.2 \pm 3.5$ & $12.1 \pm 2.7$ \\
\hline Mean fasting blood glucose, $\mathrm{mmol} / \mathrm{l}$ & $10.8 \pm 2.4$ & $10.4 \pm 3.1$ \\
\hline
\end{tabular}


Positive results of the tests for determination of CAN

\begin{tabular}{|c|c|c|}
\hline CARTs & DM 1 patients & DM 2 patients \\
\hline 1) Resting tachycardia, n (\%) & $6(20 \%)$ & $10(20 \%)$ \\
\hline 2) Standing tests for orthostatic hypotension, n (\%) & $10(33 \%)$ & $15(30 \%)$ \\
\hline 3) Valsalva maneuver, n (\%) & $9(30 \%)$ & $16(36 \%)$ \\
\hline 4) Heart rate response to deep breathing, n (\%) & $6(20 \%)$ & $8(17.8 \%)$ \\
\hline 5) Diastolic blood pressure response to sustained, n (\%) handgrip & $11(37 \%)$ & $20(44 \%)$ \\
\hline
\end{tabular}

Table 4

Stages of CAN in DM patients

\begin{tabular}{|c|c|c|}
\hline Stages of CAN with score & DM 1 & DM 2 \\
\hline 1) No CAN (score - 0), n (\%) & $13(43.3 \%)$ & $18(40 \%)$ \\
\hline 2) Early CAN (score - 1). Points 0,5-1,5, n (\%) & $7(23.3 \%)$ & $8(17.8 \%)$ \\
\hline 3) Definitive CAN (score - 2). Points 2-3, n (\%) & $7(23.3 \%)$ & $13(28.9 \%)$ \\
\hline 4) Severe CAN (score - 3). Points $\geq 3,5$, n (\%) & $3(10.0 \%)$ & $6(13.3 \%)$ \\
\hline
\end{tabular}

Relation between duration of disease and CAN in DM patients

Table 5

\begin{tabular}{|c|c|c|c|c|c|c|}
\hline \multirow{2}{*}{ DM history } & \multicolumn{2}{|c|}{ CAN presence } & \multicolumn{2}{|c|}{ CAN absence } & \multicolumn{2}{|c|}{ Total } \\
\hline & DM 1 & DM 2 & DM 1 & DM 2 & DM 1 & DM 2 \\
\hline$<10$ years & $\begin{array}{c}2 \\
(11.8 \%)\end{array}$ & $\begin{array}{c}7 \\
(25.9 \%)\end{array}$ & $\begin{array}{c}9 \\
(69.2 \%)\end{array}$ & $18(100 \%)$ & $11(36.7 \%)$ & $25(55.6 \%)$ \\
\hline$>10$ years & $13(76.4 \%)$ & $15(55.6 \%)$ & $2(15.4 \%)$ & $0(0 \%)$ & $15(50 \%)$ & $15(30 \%)$ \\
\hline Firstly & $2(11.8 \%)$ & $5(18.5 \%)$ & $2(15.4 \%)$ & $0(0 \%)$ & $4(13.3 \%)$ & $5(11.1 \%)$ \\
\hline Total & 17 & 27 & 13 & 18 & 30 & 45 \\
\hline
\end{tabular}

ties. Near $13 \%$ of DM 1 and 2 patients were hospitalized firstly because of diagnoses of DM.

Standard diabetic tests showed decompensation of DM in all patients (table 2).

Clinically $20 \%$ of DM 1 and $17.8 \%$ of DM 2 patients had palpitation, resting tachycardia, $10 \%$ of DM 1 and $11.1 \%$ of DM 2 patients felt dyspnea in physical exertions, $10 \%$ of DM 1 and $15 \%$ of DM 2 patients had weakness, dizziness, orthostatic hypotension. Clinical signs of CVD were defined in all firstly diagnosed DM 2 patients and in half of DM 1 patients. After conducting of 5 examination tests for diagnosis of CAN we analyzed next results (see table 3).

According to the literature, the resting heart rate is independently associated with CAN and has a high value in predicting CAN in the general population [13]. Development of the orthostatic hypotension suggests a relatively late complication of CAN [14] and corresponds in present study with long undiagnosed period of that diabetic complication.

Stages of CAN were based on the CART Score (see table 4).

Near half of all patients presented with early and definitive CAN, while the higher prevalence of definitive CAN was shown in DM 2 patients. Severe CAN was confirmed more often in DM 2 patients also. According to the literature, the prevalence of possible CAN and definite CAN in patients with newly diagnosed DM 2 has been reported to be $15.3 \%$ and $1.8 \%$ [15].

We analyzed and compared correlation between duration of DM and presence of CAN (see table 5).

The CAN subcommittee of Toronto consensus panel on diabetic neuropathy suggests screening for CAN in asymptomatic DM 2 pa- 
CAN and HbA1c level of DM patients

\begin{tabular}{c|c|c}
\hline Type & $\begin{array}{c}\text { Mean HbA1c } \\
\text { of-non CAN patients, \% }\end{array}$ & $\begin{array}{c}\text { Mean HbA1c } \\
\text { of CAN patients, \% }\end{array}$ \\
\hline DM 1 patients & $11.17 \pm 3.18$ & $15.26 \pm 2.54 *$ \\
\hline DM 2 patients & $8.23 \pm 2.21$ & $14.87 \pm 4.34 *$ \\
\hline
\end{tabular}

Note:

* significant difference $(\mathrm{p} \leq 0,05)$.

Sensory peripheral neuropathy among CAN patients

\begin{tabular}{c|c|c|c}
\hline Type & CAN presence & $\begin{array}{c}\text { Peripheral } \\
\text { neuropathy presence }\end{array}$ & $\begin{array}{c}\text { Peripheral } \\
\text { neuropathy absence }\end{array}$ \\
\hline DM 1, n (\%) & $17(100 \%)$ & $15(88.2 \%)$ & $2(11.8 \%)$ \\
\hline DM 2, n (\%) & $27(100 \%)$ & $19(70.3 \%)$ & $8(29.7 \%)$ \\
\hline
\end{tabular}

Diabetic retinopathy and CAN

Table 8

\begin{tabular}{c|c|c|c}
\hline Type & Diabetic retinopathy & $\begin{array}{c}\text { Diabetic retinopathy } \\
\text { with CAN }\end{array}$ & $\begin{array}{c}\text { Diabetic retinopathy } \\
\text { without CAN }\end{array}$ \\
\hline DM 1, n (\%) & $12(100 \%)$ & $9(75 \%)$ & $3(25 \%)$ \\
\hline DM 2, n (\%) & $16(100 \%)$ & $10(62.5 \%)$ & $5(31.2 \%)$ \\
\hline
\end{tabular}

tients at diagnosis and DM 1 patients with disease duration $\geq 5$ years who are at high risk [15]. Our study revealed that history of DM 1 and DM 2 more than 10 years strongly correlated with high prevalence of CAN. However, in cases of DM 1 patients suffering of disease longer than 10 years had clinically diagnosed CAN in 7 times more often than in cases of shorter disease. Concerning to patients with DM 2, longer history of DM characterised with 2 times prevalence of CAN only. All firstly diagnosed DM 2 patients presented with CAN, while half of the same DM 1 patients had not CAN in period of observation. Nobody of DM 2 patients with duration of disease longer than 10 years was free of CAN sings.

We analyzed and compared how the HbA1c level of DM patients can correlate with development of CAN (see table 6).

According to investigations, bad glycemic control increased risk of CAN development and stimulated its progression [16]. However, glycemic control of DM 1 patients was significantly worse than of DM 2 patients.
We analyzed correlation of sensory peripheral neuropathy in DM patients with development of CAN (see table 7).

Coexistence of CAN and sensory peripheral neuropathy was higher in 1,26 times in patients with DM 1 than in DM 2 patients. Absence of peripheral neuropathy in diabetic patients with CAN was in near 3 times more often in DM 2 than DM 1 patients. So, CAN predicted development of peripheral neuropathy.

We analyzed the correlation between diabetic retinopathy in DM patients with CAN (see table 8).

In DM 1, risk factors of CAN include higher levels of HbA1c, hypertension, distal symmetrical polyneuropathy, retinopathy and hyperglycemic exposure [17]. Our study revealed that coexistence of diabetic retinopathy and CAN was in 1.2 times more often in cases of DM I, $31.2 \%$ patients with DM 2 were suffering from diabetic retinopathy without signs of CAN. 30\% of all investigated DM 1 patients and $40.1 \%$ of DM 2 patients had combination of other diabetic complications with CAN. Frequency of that 
combination strongly correlated with duration of DM and level of glycemic control that is also reflected in the literature [18].

Thus, the proposed set of diagnostic measures should be obviously and easily used for the timely diagnosis of CAN in diabetic patients, especially in asymptomatic cases, and objectively assessing the effectiveness of the therapy.

\section{CONCLUSIONS}

Near $60 \%$ of investigated patients with DM type 1 and 2 were suffering from CAN. Definitive and severe CAN were closer associated with DM 2 and can be explained by long undiagnosed period of diabetes.

Development and progression of CAN strongly correlated with prolongation of DM. DM 1 history longer than 10 years associated with CAN in 7 times more often than in shorter disease. CAN in DM 2 patients with less than 10 years of DM history was diagnosed in 2.2 times more often than in DM 1 patients. All newly diagnosed DM 2 patients showed presence of CAN.

Inadequate glycemic control looks significantly worse in DM 1 patients directly corres- ponded to the development and progression of CAN.

Association of the sensory peripheral neuropathy and CAN was highly prevailed in DM 1 patients. Development of CAN predicted the manifestation of peripheral neuropathy.

Combination of the diabetic retinopathy and CAN observed more frequently in DM 1 patients. Diabetic retinopathy or CAN could develop primarily, but corresponding to the history of DM this coexistence became obvious.

Careful and easy revealing of CAN by proposed standard tests could help in proper diagnoses of diabetic complications for the effective treatment and prevention of adverse cardiovascular and cerebrovascular events of DM.

\section{REFERENCES}

1. World Health Organization. Global Report on Diabetes. 2016, available at: http://www.who.int/diabetes/globalreport/en/ on 08.29.2017.

2. International Diabetes Federation. Atlas, 7th Ed, available at: http://www.diabetesatlas.org/across-the-globe. html on 08.29.2017.

3. Matheus AS, Tannus LR, Cobas RA, et al. Int $J H y$ pertens 2013; 2013: 653789. doi: 10.1155/2013/653789.

4. Leon BM, Maddox TM. World J Diabetes 2015; 6(13): 1246-1258. doi: 10.4239/wjd.v6.i13.1246.

5. Vinik AI, Casellini C, Parson HK, et al. Front Neurosci 2018; 12: 591. doi: 10.3389/fnins.2018.00591.

6. Dyck PJ, Albers JW, Andersen H, et al. Diabetes Metab Res Rev 2011; 27: 620-628. doi: 10.1002/dmrr.1226.

7. Spallone V, Ziegler D, Freeman R, et al. Diabetes Metab Res Rev 2011; 27(7): 639-653. doi: 10.1002/dmrr.1239.

8. Pop-Busui R, Boulton AJ, Feldman EL. Diabetes Care 2017; 40: 136-154. doi: 10.2337/dc16-2042.

9. Fisher VL, Tahrani AA. Diabetes, metabolic syndrome and obesity: targets and therapy 2017; 10: 419-434. doi: 10.2147/DMSO.S129797.
10. Rolim LC, de Souza JS, Dib SA. Front Endocrinol 2013; 4: 173. doi: 10.3389/fendo.2013.00173.

11. Serhiyenko VA, Serhiyenko AA. World J Diabetes 2018; 9(1): 1-24. doi: 10.4239/wjd.v9.i1.1.

12. Bernardi L, Spallone V, Stevens M. Diabetes Metab Res Rev 2011; 27: 654-664. doi: 10.1002/dmrr.1224.

13. Tang ZH, Zeng F, Li Z, Zhou L. J Diabetes Res 2014; 2014: 215473. doi: 10.1155/2014/215473.

14. Balcıŏ̆lu AS, Müderrisoğlu H. World J Diabetes 2015; 6(1): 80-91. doi: 10.4239/wjd.v6.i1.80.

15. Menon AS, Dixit A, Garg MK, Girish R. Indian J Endocrinol Metab 2017; 21(2): 282-285. doi: 10.4103/ijem. IJEM_542_16.

16. Arif ZA, Shaikh IA, Masood N. Indian Heart J 2014; 66(6): 751-754. doi: 10.1016/j.ihj.2014.10.417.

17. Dafaalla MD, Nimir MN, Mohammed MI. Open Heart 2016; 3: e000336. doi: 10.1136/openhrt-2015-000336.

18. Andersen ST, Witte DR, Fleischer J, et al. Diabetes Care 2018; 41(12): 2586-2594. doi: 10.2337/dc18-1411. 


\title{
ДІАГНОСТИКА КАРДІАЛЬНОÏ АВТОНОМНОĪ НЕЙРОПАТІЇ У ХВОРИХ НА ЦУКРОВИЙ ДІАБЕТ
}

\author{
Шупер В. О. ${ }^{1}$, Шупер С. В. ${ }^{2}$, Рикова Ю. О. ${ }^{3}$, Трефаненко І. В. ${ }^{1}$ Шумко Г. I. ${ }^{1}$, Рева Т. В. \\ ${ }^{1}$ Буковинський державний медичний університет, м. Чернівиі, Україна; \\ 2 Чернівецький національний університет імені Юрія Федьковича, м. Чернівиі, Україна; \\ ${ }^{3}$ Харківський національний медичний університет, м. Харків, Україна \\ sssrlug@gmail.com
}

В роботі представлені результати проведеної діагностики та порівняльного аналізу частоти та інтенсивності проявів діабетичної кардіальної автономної нейропатії у хворих на ЦД 1-го та 2-го типів за допомогою стандартних діагностичних тестів. Виявлені позитивні кореляційні зв'язки між тривалістю хвороби та проявами автономної нейропатії у хворих на ЦД 2-го типу, розвитком сенсорної полінейропатії, ретинопатії та автономної кардіальної нейропатії у хворих на ЦД 1-го типу, причому це діабетичне ускладнення передувало клінічним проявам периферичної нейропатії. Запропонований комплекс діагностичних заходів дозволяе вчасно діагностувати розвиток кардіоваскулярних діабетичних ускладнень та об’ективно оцінювати ефективність проведеної терапії.

К л ючові слов а : кардіальна автономна нейропатія, цукровий діабет, діагностика.

\section{ДИАГНОСТИКА КАРДИАЛЬНОЙ НЕЙРОПАТИИ У БОЛЬНЫХ САХАРНЫМ ДИАБЕТОМ}

Шупер В. А. ${ }^{1}$ Шупер С. В. ${ }^{2}$, Рыкова Ю. А. ${ }^{3}$, Трефаненко И. В. ${ }^{1}$, Шумко Г. И. ${ }^{1}$, Рева Т. В. ${ }^{1}$

${ }^{1}$ Буковинский государственный медицинский университет, г. Чернови,ы, Украина;

2 Черновиикий национальный университет имени Юрия Федьковича, г. Черновиьь, Украина;

${ }^{3}$ Харьковский национальный медицинский университет, г. Харьков, Украина sssrlug@gmail.com

В работе представлены результаты проведенной диагностики и сравнительного анализа частоты и интенсивности проявлений диабетической кардиальной автономной нейропатии у больных СД 1-го и 2-го типов с помощью стандартных диагностических тестов. Выявлены положительные корреляционные связи между продолжительностью болезни и проявлениями автономной нейропатии у больных СД 2-го типа, развитием сенсорной полинейропатии, ретинопатии и автономной кардиальной нейропатии у больных СД 1-го типа, причем данное диабетическое осложнение предшествовало клиническим проявлениям периферической нейропатии. Предложенный комплекс диагностических мероприятий позволяет вовремя диагностировать развитие кардиоваскулярных диабетических осложнений и объективно оценивать эффективность проводимой терапии.

К л ючевые слова: кардиальная автономная нейропатия, сахарный диабет, диагностика. 


\title{
DIAGNOSIS OF THE CARDIAC AUTONOMIC NEUROPATHY IN DIABETIC PATIENT
}

\author{
V. A. Shuper ${ }^{1}$, S. V. Shuper ${ }^{2}$, Ju. O. Rykova ${ }^{3}$, I. V. Trefanenko ${ }^{1}$, G. I. Shumko ${ }^{1}$, T. V. Reva ${ }^{1}$ \\ ${ }^{1}$ Bucovinian State Medical University, Chernivtsi, Ukraine; \\ ${ }^{2}$ Yuriy Fedkovych Chernivtsi National University, Chernivtsi, Ukraine; \\ ${ }^{3}$ Kharkiv National Medical University, Kharkiv, Ukraine \\ sssrlug@gmail.com
}

Cardiac autonomic neuropathy (CAN) is a very common diabetes-related complication that has a major effect on CVD, mortality and morbidity in patients with DM. Careful and timely testing of CAN with easy standard bedside tests in patients with DM 1 and 2 is critically important for early diagnoses and prophylaxes of further CV complications.

Aim of the study was to evaluate the CAN characteristics in DM 1 versus DM 2 patients and to identify the relationship between $\mathrm{CAN}$ and typical diabetic complications.

Materials and methods. A descriptive and comparative cross-sectional study was developed with 75 patients with Diabetes Mellitus (DM $1-30$ patients, DM $2-45$ patients) who were hospitalized to the endocrinology department for treatment. All patients were investigated routinely - complains, anamnestic data, objective examination, lab and instrumental examination. For defining of CAN next five classical tests were done (cardiac autonomic reflex testing (CART)): Evaluating of the Resting tachycardia; Heart rate response to deep breathing; Valsalva maneuver; Systolic blood pressure response to standing; Diastolic blood pressure response to sustained handgrip.

Results and discussions. Absence of CAN, according to proposed score, was defined in those patients without clinical features of CVD. $46.8 \%$ of all patients presented with early and definitive CAN, while the higher prevalence of definitive CAN was diagnosed in DM 2 patients. Severe CAN was confirmed more often in DM 2 patients also. Coexistence of CAN and peripheral neuropathy was higher in patients with DM 1 than in DM 2 patients. Among DM 1 patients with CAN only 11.8\% persons had not sensory peripheral neuropathy, while $29.7 \%$ DM 2 patients with CAN, were free of sensory peripheral neuropathy. Positive correlations were found between the duration of the DM and manifestations of CAN in patients with DM II, the development of sensory polyneuropathy, retinopathy and CAN in patients with DM I, and this diabetic complication preceded the clinical manifestations of peripheral neuropathy.

Thus, the proposed set of diagnostic measures should be obviously and easily used for the timely diagnosis of CAN in diabetic patients, especially in asymptomatic cases, and objectively assessing the effectiveness of the therapy.

Key words: cardiac autonomic neuropathy, Diabetes Mellitus, diagnosis. 